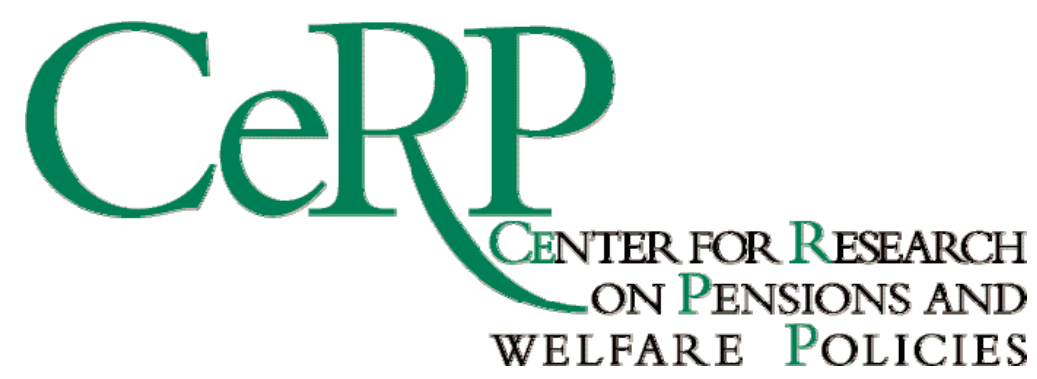

Working Paper 140/14

SEVEN WAYS TO KNIT YOUR PORTFOLIO: IS INVESTOR COMMUNICATION NEUTRAL?

\author{
Cecilia Boggio \\ Elsa Fornero \\ Henriette Prast \\ Jose Sanders
}




\title{
Seven Ways to Knit Your Portfolio: Is Investor Communication Neutral?
}

\author{
Cecilia Boggio ${ }^{\dagger}$ \\ Elsa Fornero \pm \\ Henriette Prast* \\ Jose Sanders\# \\ †Università di Torino and CeRP-CCA, Italy \\ \pm Università di Torino and CeRP-CCA, Italy \\ * Tilburg University and Netspar, The Netherlands \\ \#Radboud University Nijmegen, The Netherlands
}

This version: October 2014

\begin{abstract}
The concept of "familiarity" has been used in financial economics to explain apparent paradoxes in people's behavior, such as the home bias in portfolio choices. In this study, we investigate whether (lack of) familiarity with the language of investor communication may contribute to an explanation of the well-documented gender gap in financial decision-making (i.e. women participate less in the stock market than men and, if they do, they take less risk than men). Using an interdisciplinary framework that combines insights from Behavioral Economics, Finance, Social Psychology and Linguistics, we analyze the metaphors used in websites that target beginning retail investors in three different languages; Dutch, Italian and English UK. We find that in all three languages the metaphors used come from the same conceptual domains; namely, war, health, physical activity, game, farming and the five senses. As these domains refer to worlds that are predominantly and (stereo)typically masculine, we conclude that the language of investor communication may give rise to feelings of familiarity and belonging among men, while creating feelings of distance and non-belonging among women. In other words, just as emotional responses influence risk assessment and return expectations, the language used in financial communication may contribute to explaining the gender gap in stock market participation, risk taking and portfolio choice.
\end{abstract}

Keywords: familiarity, gender gap, investor behavior, financial communication

JEL Codes: G02, G11, D14, D18, J16 
Acknowledgments: The first draft of this paper was written while Henriette Prast was Visiting Research Scholar at the Collegio Carlo Alberto (Moncalieri, Torino, Italy) in September 2013, for which she is very grateful. The authors would like to thank Serena Boccardo, Olga Leonhard and Noortje Martens for excellent research assistance. Moreover, without implicating, the authors would like to thank the participants at the lunch seminar at Collegio Carlo Alberto on September 27, 2013, the participant at a seminar at the research department of the Consob (Financial Market Authority), Rome, on September 30, 2013, the participants at the Summer School on Gender, Economics and Society (July 7-14, 2014, Torino, Italy), the participants at the Labsi Workshop (Siena, Italy, September 11-12, 2014), and Joep Cornelissen and Gerard Steen for valuable comments and suggestions.

$* * * * * * * * *$

It's only natural that it will strike some as strange that an inn located in Italian territory should have a German name, but that is easily explained when we remember that most of the guests who come here are Austrians and Germans who like to feel at home [emphasis added].

(José Saramago, The Elephant's Journey, 2010)

\section{Introduction}

In this paper we investigate whether the language used in communication with financial consumers could create psychological closeness among men, not women. If so, it could be a factor influencing the gender gap in financial attitudes and behavior. Marketing practice and research finds that words influence consumers' attitudes and behavior through creating conceptual associations, and that they may have a different impact on men and women. A recent Harvard business case serves as an illustration (Avery 2012). While women liked Diet Coke from the start (1983), the Coca Cola Company managed to get men to consume its zero-calorie cola only after introducing Coca Cola Zero (2005). Quite obviously, while "Diet" evokes associations with a stereotypical woman's world (where she is overly concerned with her looks and physical attractiveness), "Zero" evokes associations with a stereotypical man's world (where he is strong, tough, has quantitative skills and is a "black and white" thinker).

It is well known from finance theory that people prefer to invest more in the familiar (e.g. Huberman 2001). The psychological mechanism underlying the effect of familiarity can be found in neuroscience and social psychology research. If we have pleasant feelings about an activity, we perceive the benefits as high and the risks as low. On the other hand, if we have 
unpleasant feelings about an activity, we are more likely to perceive the risks as high and the benefits as low. Familiarity -a close association with someone or something-very often creates a positive emotional response and is therefore relevant for investment behavior. Existing studies into the role of familiarity in influencing investor behavior have focused on the effect of physical closeness. This is not surprising as the aim was to explain the investor's home bias.

This paper hypothesizes that also psychological closeness, through feelings of familiarity and belonging, may create a positive emotional response and, hence, influence investment decisions (participation, portfolio choice). If words evoke conceptual associations that create psychological closeness, they may have an impact on investor behavior in a similar way as geographical closeness. However, the effect may differ between the genders if the language used evokes a sense of familiarity for one of the genders, and not for the other. Thus, we investigate whether the language of investor communication could result in degrees of psychological closeness that differ between the genders. If that were the case, it could contribute to explaining the gender gap in self-assessed financial risk attitudes, stock market participation and portfolio choice. ${ }^{1}$ Explaining the gender gap is not merely of academic interest. It is important in a world in which financial risk is shifted toward individuals, labor market participation of women increases, and women (need to) rely more on themselves financially. In fact, the OECD has called for reducing the gender gap and creating financial inclusion of women, a plea supported by the G20 Ministers of Finance and Central Bank Governors in July 2013, and the G20 Leaders in September 2013 (OECD, 2013a; European Commission/G20, 2013). ${ }^{2}$

As countries differ in their spoken and written language, and as the gender gap in financial decision-making has been documented in many countries, we study investor communication in different languages in order to be able to draw general, even though preliminary, conclusions. 3 Our findings indicate that for the three languages taken into consideration (Dutch, English UK, and Italian) the metaphors in investor communication come from the same conceptual domains: WAR, HEALTH, PHYSICAL ACTIVITY, GAME, FARMING and the FIVE SENSES. 4 This regularity is in line with Lakoff and Johnson's conceptual metaphor theory (1980), which argues that the use of metaphors, even though not deliberate, is

\footnotetext{
${ }^{1}$ Birghenti and Lucarelli (2013) find that unbiased risk attitudes (measured through reaction of the skin) differ from self-declared risk tolerance. Skin reactions of men reveal a lower tolerance to risk than they have declared, while women's skin reactions reveal a higher risk tolerance than the self-declared one. As a result, unbiased risk tolerance does not differ between men and women.

2 For an overview of the evidence on pension awareness and literacy see Prast and Van Soest 2014.

3 In this paper, we do not carry out a comparative analysis, leaving that to future research.

${ }^{4}$ A conceptual domain is the representation of any coherent segment of human experience, such as the concept of love or journey.
} 
far from being random. As these conceptual domains can be sex-typed as predominantly masculine, the metaphorical language used may give rise to feelings of familiarity and belonging among men, while creating feelings of distance and not-belonging among women. In other words, as emotional responses influence risk assessment and return expectations, the language used may contribute to explaining the gender gap in stock market participation and portfolio choice.

\section{Theoretical background}

People deal with reality not only in an analytical, rational way, but also in an intuitive, narrative way (Epstein, 1994). In social psychology, a Dual Process Theory provides an account of how a phenomenon can occur as a result of two different processes or systems. More specifically, when referred to our way of reasoning, the two systems that come into play are System 1 and System 2 where the former is an implicit (i.e. automatic, unconscious) mental process and the latter is an explicit (i.e. controlled, conscious) mental process (Slovic et al 2005). In a similar way, neuroscientists define as affect heuristic the phenomenon that behaves as a first and fast response mechanism in decision-making. ${ }^{5}$ As mentioned in the Introduction, people have instinctive emotional responses (or affects) in a risky environment, instead of, or in addition to, logical ones. Whereas positive affect decreases perceived risk, negative affect increases it (Zajonc 1968, 1980). In other words, the affect heuristic is a swift, involuntary response to a stimulus that speeds up the time it takes to process information. This is especially interesting in the context of investor decision-making as positive (negative) affect, besides decreasing (increasing) perceived risk, also leads to a higher (lower) estimate of return (Alhakami and Slovic 1994). Heath and Tversky (1991) find that people prefer to bet on their own judgment in a context where they feel competent, where their "feeling of competence is enhanced by [...] familiarity", and, in turn, familiarity results in less ambiguity aversion, i.e. a preference for gambles with known probabilities over gambles with ambiguous probabilities (Ellsberg 1961; Merton 1987; Boyle et al 2013; Dimmock et al 2013). We can then infer that, as far as investment behavior is concerned, "familiarity" very often creates a positive affect which may

\footnotetext{
${ }^{5}$ In cognitive psychology, "heuristics" are simple, efficient rules which people often use to form judgments and make decisions. In a nutshell, they are mental shortcuts that usually involve focusing on one aspect of a complex problem and ignoring others.
} 
explain why "people invest in the familiar while often ignoring the principles of portfolio theory" (Huberman 2001).

The concept of familiarity -a close association with someone or something - has been used to explain why investors hold much more stock from their home country than theory would predict, diversifying less than would be optimal according to finance theory (French and Poterba 1991, Tesar and Werner 1996). This home bias has not disappeared with developments in ICT and with the removal of institutional barriers like capital controls. There is even a local bias, with US investors holding more stock from companies operating locally (Coval and Moskowitz, 1999). Geographical closeness is not the only determinant of familiarity. Employees hold a large faction of their pension wealth in employer stock, even after Enron (Laibson, 2005), and Doskeland and Hvide (2011) find that after excluding employer stock holdings, employees overinvest in stocks of companies in the industry they work for, which may or may not be geographically close. Along similar lines, Prast et al (2013, 2014), taking the influence of affect on risk perception and return expectations as their point of departure, study whether the gender gap in stock market participation and risk taking is influenced by familiarity with the companies most traded in the stock market, which are mainly heavy industries. Assuming that women are more exposed to advertisements in women's magazines than men, they construct a "pink" index and study whether the gender gap differ according to whether participants are allocated to the pink, or to the traditional stock market ("blue") condition. They find that in the blue condition it takes women three times as long to decide as men, while in the pink condition women decide quicker, and that women aged 60 and over take more risk in the pink than in the blue condition.

The familiarity explanation of all the above well-documented investor biases can be formalized with the Merton model (1987) which shows that even in a perfect market an investor may hold only a subset of all securities available, as long as he "uses security $\mathrm{k}$ in constructing his optimal portfolio only if the investor knows about security k", where "knowing about" is not to be understood as "having information about" but, rather, as "being aware of," or "being familiar with".

Not only acquaintance with particular names and concepts, but also language use in general is very powerful in creating feelings of familiarity or exclusion, with conceptual associations playing an important role, as evidenced in marketing. In abstract conceptual domains, people use, often unconsciously, metaphors to make concepts and actions "imaginable". A picture can tell a thousand words, but a metaphor can create a "picture" and influence feelings and even drive behavior. The word "metaphor" derives from the Greek verb 
$\mu \varepsilon \tau \alpha \varphi \varepsilon ́ \rho \varepsilon ı v$ ('to carry across'). In fact, metaphors are words and expressions transferred from one conceptual domain or meaning to another. This carrying across necessarily makes some aspects of reality (the object, concept, action it is meant to describe) vivid, while "hiding" others (Ortony, 1993). Depending on, for example, the receiver's social identity, they may therefore create feelings of belonging or distance. ${ }^{6}$ Let's take the Diet Coke case as an example once again. Apparently the word "diet" evokes images of a woman's world: buying and fitting clothes, spending a lot of time in front of the mirror. The word "zero," on the other hand, may create metaphorical associations of power (zero tolerance, all or nothing, quantities, which may explain its appeal to men.7

The conceptual domain object of our analysis, Finance, is definitely an abstract domain, and "market" and "level playing field" are examples of frequently used metaphors within this domain. "Level playing field" makes the competitive aspect vivid (one may win or lose), while "hiding" the fact that one may wish to participate in the stock market not to beat someone else, but to realize a future living standard. Note, however, that although a hidden aspect may be not applicable, by using the metaphor it may be evoked in association nonetheless. Precisely these evocations may cause feelings of (un)familiarity. The examples of "market" and "level playing field" also illustrate that metaphors may (as in market) or may not (as in level playing field) be the result of changes in the concept over time. Originally the trading in assets did take place on a physical market, and nowadays the "market" metaphor is used for the abstract concept of the meeting of demand and supply. But financial markets were never anything like a physical playing field as in sports.

\footnotetext{
${ }^{6}$ Driver Leinbach et al (1997) find that among 4-year olds "teddy bear" is considered, by both boys and girls, as masculine, even though there exist as many female as male bears.

7 Social psychology research shows how real images can influence people's behavior without people being aware of it ("priming effect"). A famous example is Aarts and Dijksterhuis (2003) who show that exposing people to a picture of a library induces them to be more quiet. Wheeler and Berger (2007) find that the same "prime" affects behavior differently (even in opposite directions) depending on whether consumers are men or women.
} 
Figure 1. Structure of a conceptual metaphor.

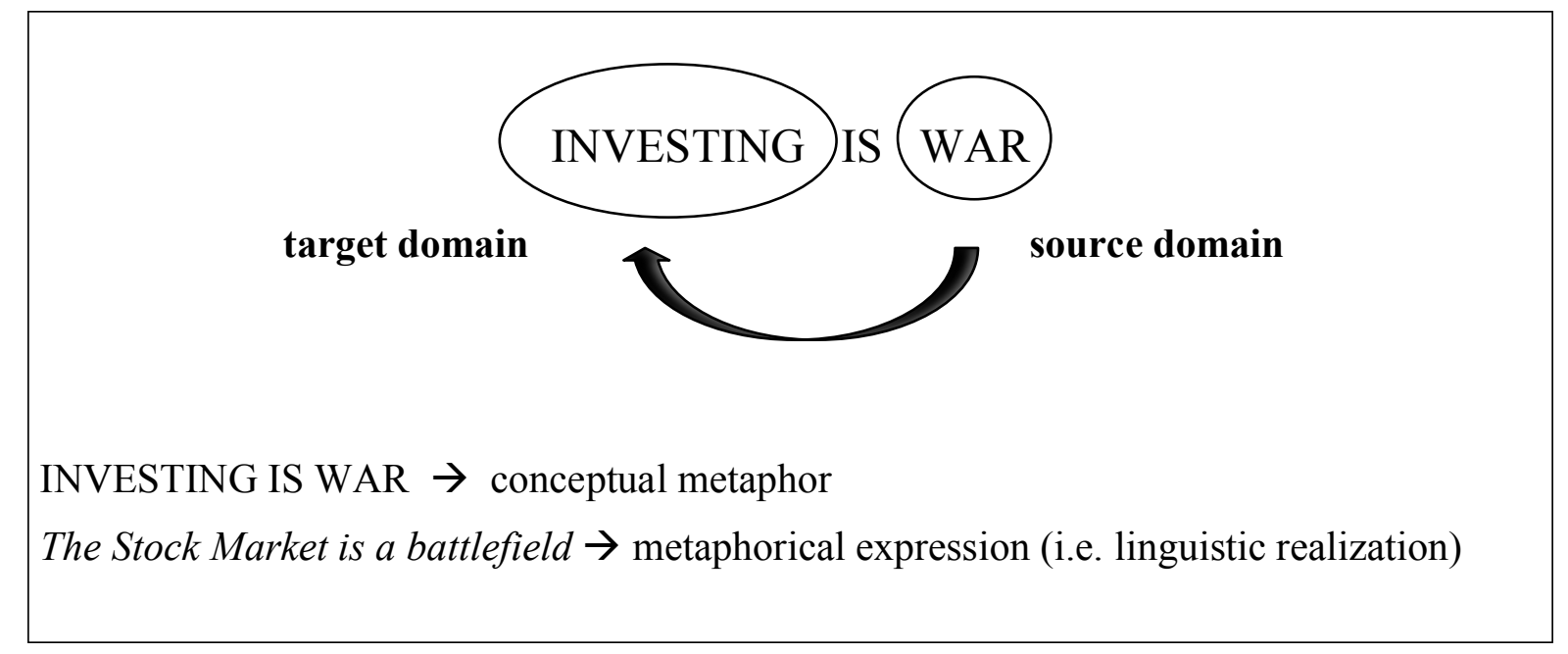

Using cognitive (or conceptual) metaphor theory (Lakoff and Johnson, 1980; 2008), we investigate the possibility that investor communication evokes a sense of familiarity for one of the genders, and not for the other. This theory was first spelled out by Lakoff and Johnson's seminal work Metaphors We Live By (1980) and it has since become the standard in linguistic metaphor research. Cognitive metaphor theory rejects the notion that metaphor is a decorative device, peripheral to language and thought. Instead, the theory holds that metaphor is central to thought. Language, and metaphors in particular, is what makes our thoughts (conceptual systems) visible. Particularly in abstract domains/disciplines, such as Finance, people use, often unconsciously, metaphors to make concepts and actions "imaginable," more vivid, easier to understand. As Figure 1 illustrates, the classical cognitive view on metaphors holds that metaphor is a conceptual phenomenon that is realized at the surface level of language. A certain target domain (INVESTING) "borrow words" from a certain source domain (WAR) in order to turn an abstract concept or experience into a more "imaginable" one. To put it another way, there are two main roles for the conceptual domains posited in conceptual metaphors: 1) source domain: the conceptual domain from which we draw metaphorical expressions (e.g. investing is war); 2) target domain: the conceptual domain that we try to understand (e.g. investing is war).

Examples of studies analyzing metaphors in Economics are Boers and Demecheleer (1997), who find that the metaphors used in The Economist, Business Week, The Financial Times, and Fortune and come from the source domains journey ("path"), health, war, mechanics, gardening, and food, and Koller (2004) who finds that in mergers and acquisitions texts evolutionary struggle metaphors prevail, while Guo (2013) concludes that the metaphors used in the Chinese media coverage of the acquisition by Geely's of Volvo come from the source 
domains marriage, journey, health, and war. ${ }^{8}$ Morris et al (2005) study the occurrence and effect of metaphors used by stock market commentators. They distinguish between agent metaphors and object metaphors. Agent metaphors describe stock price movements in terms of an action - the result of an intention. Examples mentioned by Morris et al are "the Dow fought its way upward," and "the S\&P dove like a hawk." Object metaphors, on the other hand, describe stock price movements as the result of an external physical force: "the Nasdaq dropped off a cliff," "the S\&P bounced back." They find that the use of these metaphors is not random, with agent metaphors used more often when the stock market went up. Moreover, they find that metaphor use affects investor expectations: agent metaphors increase the probability that investors expect a stock price trend to continue. 9

The purpose of this paper is quite innovative. We analyze the language used in websites that address financial consumers who are looking for information on how to start investing, apply metaphor analysis to categorize the metaphors according to their source domain, and discuss whether these could create feelings of belonging or distance depending on the gender of the reader, and therefore may contribute to a gender difference in investment attitudes and behavior through the channel of familiarity.

\section{Methodology}

Before turning to the methodology we have used in our study, it is useful to devote a few lines to (the detection of) metaphors. In order to be able to quantify (types of) metaphors in (large) written and spoken texts, it is important to have a rigorous "objective" method. This is also important if one wants to compare findings across different languages. Since researchers may differ in their intuitions about what constitutes a metaphoric expression, it is important that they have explicit criteria for categorization, especially if they analyze different texts in different languages, and even more so if they want to compare findings across different languages. In this paper, we analyze three short texts in three different languages, and the composition of our

\footnotetext{
${ }^{8}$ Chen (2013) discovers a relationship between the way a language encodes time, and the inter-temporal decision making of its speakers. Liang et al (2014) find a relationship between the language a company uses in its annual report, and its efforts at corporate social responsibility.

9 Although not applied in our study, it is worth mentioning that another common way of categorizing verbal metaphors is by distinguishing living metaphors from dead and moribund metaphors (Lakoff and Johnson 1980; Lakoff and Turner 1989; Müller 2008).
} 
research team --including our research assistants-- was such that for each text at least three of us were able to compare the findings and create a common inventory. ${ }^{10}$

We selected three website targeting beginning retail investors, from different languages: Italian, Dutch, and English. These languages have in common that they are European, but they have different origins: Romance (Italian) vs. West Germanic (Dutch, English). English is a lingua franca (Crystal 2003), that is as a common means of communication among speakers of different first languages. By the way, these languages also differ in the gender system of their grammar, which has been measured based on various indices, which are then used to measure their affect on labor market and political participation of women (Gay et al, 2013; Santacreu et al, 2013). We should point out, however, that the purpose of this paper is NOT to compare and analyze differences between the languages. Rather, we focus on similarities: can metaphors used in investor communication in different languages be traced back to similar source domains?

The texts were taken from the following websites:

- Italian: Investire in borsa - corso pratico per principianti (http://www.windoweb.it/dossier/investire_in_borsa/guadagnare_in_borsa_1.htm)

- Dutch: Beleggen voor beginners (http://www.beleggenvoorbeginners.org/)

- English: The beginner's guide to investment (http://www.which.co.uk/money/savingsand-investments/guides/the-beginners-guide-to-investment/)

The above websites were chosen for a number of reasons. First, as our ultimate goal is to study a potential effect of investor language on stock market participation and risk taking of men and women, we need to study the texts that potential investors get to read. Ideally, we should of course analyze all media in order to analyze investment language encountered by all financial consumers, not merely the visitors of beginning investor websites, which is already a biased group. However, this was not feasible, and beginning investor websites is second-best as they constitute a "portal" target in an audience of financial consumers who do not yet invest in the stock market. Second, these sites score highest on Google when searching, in each language, for a combination of the words indicating "beginner" and "investment". Third, being beginner's guide to investment, they try to avoid the highly specialized vocabulary of the field as much as

10 This research strategy is only possible for a small text sizes like the ones we chose to study. In future work analyzing larger bodies of text we will need to apply the metaphor identification procedure developed by the Pragglejaz group (Steen, 2007). 
they can. Finally, the sites are more or less comparable length-wise, and content-wise they give beginning investors similar guidelines. In total, it is an admittedly limited corpus but worthwhile as a starting point, since, to our knowledge, there are no existing corpora about the language of investment. ${ }^{11}$

As our starting point in the analysis, we adopted the methodology of Steen's (2004) guideline for identifying metaphorically used words and concepts: "Check whether words referring to entities, properties of entities, or relations between entities in the text world do so literally, that is, directly, or whether they (can) invoke another, especially more concrete or typical, domain of usage." Note that the etymology of words is interesting in this respect, but not decisive. For instance, the word "capital" is etymologically related to the classical Latin noun "caput" which means "head," the most important part of the body; but since its common domain of use is now the economic context, we have not identified it as a metaphor. Interestingly, by the way, is that the Dutch use the word hoofdsom to indicate the sum of money invested, or lent, without the accrual of interest, where hoofd means head and sum means amount.

The procedure of analysis was as follows. First, the complete text of the three websites mentioned above was downloaded. Then, parts of the website recognizable as advertisements or news stories were omitted. Subsequently, the remainder of each text was scrutinized for words referring to entities, properties of entities, or relations between entities in the text world from domains of usage that are not literally intended, but invoke the domain of usage of financial investing; these words were identified as metaphors. Each individual case of a metaphor (metaphorical expression or linguistic realization) was reported as such and noted with its immediate context (surrounding words) and with its domain of use. In the process of metaphor identification, we used conceptual domains of the abovementioned sources as our guides, such as war, physical activity, game, health, farming and the five senses. All authors of this paper have near native fluency in English, two are native speakers of Dutch, two are native speakers of Italian and one is fluent in Italian. As for the three research assistants, they also are fluent in at least two of the three languages. This made it possible to have each text examined by at least two authors. The analysts compared the metaphors found and on that basis, distinguished a closed set of overarching source domains to be used to categorize the metaphors found in the investment texts. The complete analyses were checked with a second analyst, and all cases of

\footnotetext{
${ }^{11}$ Corpora (sing. corpus) are the object of analysis of Corpus Linguistics, a method of carrying out linguistic analyses. A "corpus" is a collection of texts (both written and spoken) involving authentic cases of language use as it occurs in the 'real world' which is electronically stored and available to be sampled and analyzed.
} 
differences in metaphor identification or categorization, the interpretation was discussed until agreement was reached, so that the metaphor identification is the result of shared analysis.

\section{Findings}

Table 1 presents an overview of the most frequent metaphors found in the beginner's investment web texts. ${ }^{12}$

${ }^{12}$ A full list of metaphors as well as their categorization into source domain can be obtained from the authors. 
Table 1. Summary statistics.

\begin{tabular}{|c|c|c|c|}
\hline & Dutch & Italian & English \\
\hline $\begin{array}{l}\text { Number of words used in } \\
\text { full text }\end{array}$ & 6,023 & 3,761 & 3,735 \\
\hline $\begin{array}{l}\text { Number of different } \\
\text { metaphors found }\end{array}$ & 45 & 35 & 39 \\
\hline $\begin{array}{l}10 \text { most frequently used } \\
\text { metaphors (with } \\
\text { frequency of their } \\
\text { linguistic realizations) }\end{array}$ & $\begin{array}{l}\text { goed/slecht doen [to do } \\
\text { well/bad] (19) } \\
\text { stijgen/dalen [rise/fall] } \\
(11) \\
\text { turbo/sprinter (11) } \\
\text { spreiding/spreid } \\
\text { [dispersion/to spread] } \\
\text { (10) } \\
\text { verlies [loss] (8) } \\
\text { winst [profit] (8) } \\
\text { partij [party] (8) } \\
\text { hefboom [leverage] (6) } \\
\text { doel/doelstelling [target] } \\
\text { (5) } \\
\text { moeilijk/makkelijk } \\
\text { [difficult/easy] (5) }\end{array}$ & $\begin{array}{l}\text { scendere/salire [rise/fall] } \\
(23) \\
\text { andare bene/male [to do } \\
\text { well/bad] (17) } \\
\text { oscillazione/oscillare } \\
\text { [fluctuation/fluctuate] (7) } \\
\text { sano/malato [healthy/ill] } \\
\text { (7) } \\
\text { tranquillo/nervoso } \\
\text { [calm/nervous] (6) } \\
\text { reazione/reagire } \\
\text { [reaction/to react] (4) } \\
\text { armi/armare [arms/to } \\
\text { arm] (2) } \\
\text { centrare/mancare [to } \\
\text { hit/to miss] (2) } \\
\text { correre un rischio [to run a } \\
\text { risk] (2) } \\
\text { giocare [to play] (2) }\end{array}$ & $\begin{array}{l}\text { rise/fall (24) } \\
\text { grow/growth (16) } \\
\text { lump sum (14) } \\
\text { protection/to be } \\
\text { protected (12) } \\
\text { to spread (10) } \\
\text { fluctuation (8) } \\
\text { loss (6) } \\
\text { to be good/bad (4) } \\
\text { impact (4) } \\
\text { step (in) (3) }\end{array}$ \\
\hline
\end{tabular}

Table 1 shows that while some metaphors appear in the top ten for all three languages (e.g. "rise/fall," words and phrases expressing upward and downward movements of quantities of money), there are also differences between the languages (e.g. (1) there are significantly more metaphors belonging to the source domain of "war" in the Dutch and English texts than in the Italian one; (2) neither the Dutch nor the Italian texts contain "growth" metaphors but there are 16 of them in the English text). The analysis of the similarities and differences would be 
interesting in itself (apart from the gender familiarity issue), but it is not the subject of this paper. Still, we would like to draw attention to the fact that although the Dutch text contains many more words than the Italian and English texts, the number of metaphors is larger in the Italian and English texts than in the Dutch text.

After having identified the metaphors used, we proceeded in allocating them to a source domain (see previous section for methodology). We found that the majority of metaphors can be allocated to one of six different source domains: (1) PHYSICAL ACTIVITY: movement (i.e. going fast/slow or up/down) vs. (de)construction (i.e. building or destroying); (2) HEALTH (including well-being, illness and death); (3) WAR (i.e. conflict), (4) GAME: play (i.e. games with rules) vs. chance (i.e. risk, gambling), FARMING, and the FIVE SENSES.

Table 2. Frequent metaphors in the three languages, by source domain.

\begin{tabular}{|c|c|c|c|}
\hline & Dutch & Italian & English \\
\hline $\begin{array}{l}\text { Most } \\
\text { frequently } \\
\text { used } \\
\text { metaphors by } \\
\text { source } \\
\text { domain (with } \\
\text { frequency) }\end{array}$ & $\begin{array}{l}\text { PHYSICAL ACTIVITY: } \\
\text { - stijgen/dalen (11) } \\
\text { - turbo/sprinter (11) } \\
\text { - spreiding/spreid (10) } \\
\text { - heefboom [leverage] (6) } \\
\text { HEALTH: } \\
\text { - goed/slecht doen (19) } \\
\text { - moeilijk/makkelijk } \\
\text { [difficult/easy] (5) } \\
\text { WAR: } \\
\text { - verlies (8) } \\
\text { - winst (8) } \\
\text { - partij (8) } \\
\text { - doel/doelstelling (5) } \\
\text { GAME: } \\
\text { - gambling (4) } \\
\text { FARMING: } \\
\text { - opbrengst [yield] (1) }\end{array}$ & $\begin{array}{l}\text { PHYSICAL ACTIVITY: } \\
\text { - salire/scendere (23) } \\
\text { - oscillazione/oscillare (7) } \\
\text { HEALTH: } \\
\text { - andare bene/male to do } \\
\text { well/bad (17) } \\
\text { - sano/malato (7) } \\
\text { - tranquillo/nervoso (6) } \\
\text { WAR: } \\
\text { - reazione/reagire (4) } \\
\text { - armi/armare (2) } \\
\text { - centrare/mancare (2) } \\
\text { GAME: } \\
\text { - correre un rischio (2) } \\
\text { - giocare (2) } \\
\text { FARMING: } \\
\text { - dare i frutti [to yield } \\
\text { benefits] (1) }\end{array}$ & $\begin{array}{l}\text { PHYSICAL ACTIVITY: } \\
\text { - rise/fall (24) } \\
\text { - to spread (10) } \\
\text { - fluctuation (8) } \\
\text { - step (in) (3) } \\
\text { HEALTH: } \\
\text { - to be good/bad (4) } \\
\text { WAR: } \\
\text { - protection/to be } \\
\text { protected (12) } \\
\text { - loss (6) } \\
\text { - impact (4) } \\
\text { GAME: } \\
\text { - to beat st/sm (2) } \\
\text { FARMING: } \\
\text { - growth/grow (16) }\end{array}$ \\
\hline
\end{tabular}

Frequencies of all metaphors for each of the above source domains are given in Table 3 and 
graphically presented in Figure 2.

Table 3. Metaphors by source domain, absolutes and proportions.

Language

\begin{tabular}{|c|c|c|c|}
\hline Source domains & Dutch & Italian & English \\
\hline $\begin{array}{c}\text { Physical Activity } \\
\text { speed/motion } \\
\text { (de) } \text { contruction }\end{array}$ & $58(41 \%)$ & $36(39 \%)$ & $69(47 \%)$ \\
\hline Health/Well-being & 31 & 34 & 44 \\
27 & 25 \\
\hline War/Conflict & $30(21 \%)$ & $33(36 \%)$ & $17(11 \%)$ \\
\hline Game (play/chance) & $36(25 \%)$ & $10(11 \%)$ & $24(16 \%)$ \\
\hline Farming & $12(9 \%)$ & $9(10 \%)$ & $4(3 \%)$ \\
\hline Senses & $2(1 \%)$ & $1(1 \%)$ & $32(22 \%)$ \\
\hline Total & $4(3 \%)$ & $3(3 \%)$ & $148(100 \%)$ \\
\hline
\end{tabular}

Figure 2. Metaphors according to source domains, percentages per language, adding up to 100 for each language.

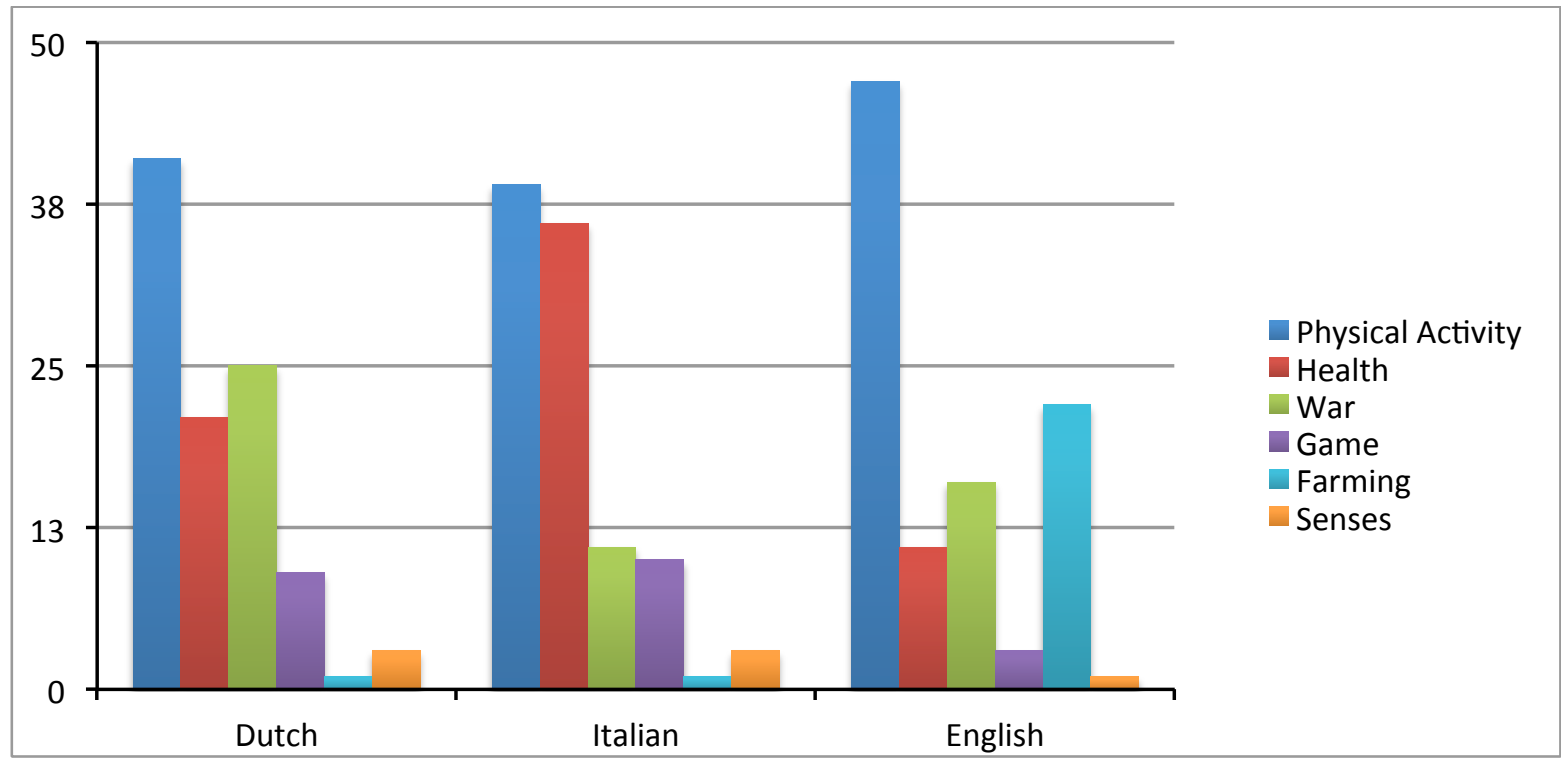


From a first inspection of the data given in Tables 1 through 3, several things stand out. First, the source domains of the metaphors are the same in all three languages. Second, some of these domains are similar to the ones found in metaphor analysis of business texts (see Section 4) notably WAR and HEALTH, while others are not. While in business texts MARRIAGE is a frequent metaphor, it is absent in the texts we analyzed, most likely because business texts often talk about mergers and acquisitions between/of companies, whereas our texts address financial consumers.

Even though the categorization of the source domains according to their familiarity to men and women requires additional research, our results allow us to make some first comments based on the source domains of the most frequent metaphors. How should we categorize PHYSICAL ACTIVITY, HEALTH, WAR, GAME, FARMING and the FIVE SENSES based on their gender familiarity? We decided to take as a reference point of our categorization the Bem Sex-Role Inventory (Bem 1974), a still widely used instrument in measuring gender role perceptions. To give only an example, according to the BSRI, women are assumed to be understanding, caring and loving whereas men are assumed to be competitive, willing to fight and take risks. ${ }^{13}$ Since the year it was published, decades have passed in which gender roles have changed. Nevertheless, a study published in 1998 concluded that the BSRI was still valid (Holt and Ellis, 1998). It can therefore be safely assumed that, despite trends toward egalitarianism in Western societies, in the $21^{\text {st }}$ century essential imagery and metaphorical framing are still different between women and men.

Our first guess, therefore, was that PHYSICAL ACTIVITY, WAR and GAME are source domains that correspond to worlds that feel more familiar to men than to women. Also the decision to consider HEALTH, FARMING and the FIVE SENSES as source domains that are in a neutral -rather than feminine--position regarding gender was made with an eye on the BSRI. Further linguistic evidence confirmed our decision. After examining linguistic research into the language of health and illness, we realized that, despite the large body of empirical research that supports the popular belief that there's a lack of expressiveness in relation to men's physical and emotional health issues, Charteris-Black and Seale (2010) have recently demonstrated that both men and women talk about their health issues. What is different are the ways - both at a grammatical and lexical level-- in which men and women talk about their health issues

${ }^{13}$ The Bem Sex-Role Inventory (BSRI) is a questionnaire created by American psychologist Sandra Bem in 1974 in an effort to measure psychological androgyny and provide empirical evidence to show the advantage of a shared masculine and feminine personality versus a sex-typed categorization. The test is formatted with 60 different personality traits (i.e. adjectives). Participants rate themselves on each trait based on a 7 point-scale. Traits are evenly dispersed, 20 masculine, 20 feminine, and 20 filler traits thought to be gender neutral. 
(Seymour-Smith et al 2002). This, however, is not relevant for our present study. The same decision was taken in relation to the source domain SENSES. There are few sensory metaphors in our corpus but they appear in all three texts (and thus languages). An obvious question is whether the domain of the FIVE SENSES should be considered an neutral or a feminine domain. An argument for the latter option could be that, generally, women are considered more "sensitive" than men, and that they "feel" more than men. However, linguistic evidence underscores that sensory metaphors are universally used (i.e. used across families of languages and cultures), as they are more memorable than their semantic analogues (Akpikar and Berger, 2012). This is due to their higher sensory nature and associative cues (e.g. "a cold person" is more memorable than "an unfriendly person", see Sadoski et al., 1993). Moreover, as Akpinar and Berger (2012) have demonstrated, given the basic nature of sensory experience, sensory metaphors provide a common ground for social interaction inasmuch as referring to universally shared human experiences -those of the five senses-- strengthens social bonds, enhances conversation flow, and fosters the exchange of ideas among people, independently of their gender. In conclusion, our categorization does not include a source domain women identify more with than men. This implies the number of metaphors found according to their familiarity to each gender, for each of the three languages separately illustrated in Table 4.

Table 4. Metaphors according to their gender familiarity based on the BSRI, proportions.

Language

Dutch Italian English

\begin{tabular}{|c|c|c|c|c|c|c|c|c|c|}
\hline $\begin{array}{c}\text { Familiarity } \\
\text { Source domain }\end{array}$ & F & M & N & F & M & N & F & M & N \\
\hline $\begin{array}{c}\text { PHYSICAL } \\
\text { ACTIVITY }\end{array}$ & & 41 & & & 39 & & & 47 & \\
\hline HEALTH & & & 21 & & & 36 & & & 11 \\
\hline WAR & & 25 & & & 11 & & & 16 & \\
\hline GAME & & 9 & & & 10 & & & 3 & \\
\hline FARMING & & & 1 & & & 1 & & & 22 \\
\hline SENSES & & & 3 & & & 3 & & & 1 \\
\hline Total & & 75 & $\mathbf{2 5}$ & & $\mathbf{6 0}$ & $\mathbf{4 0}$ & & $\mathbf{6 6}$ & $\mathbf{3 4}$ \\
\hline
\end{tabular}

F: Feminine source domain M: Masculine source domain $\mathrm{N}$ : Neutral source domain 
Figure 2. Distribution of metaphors over masculine and neutral source domains.

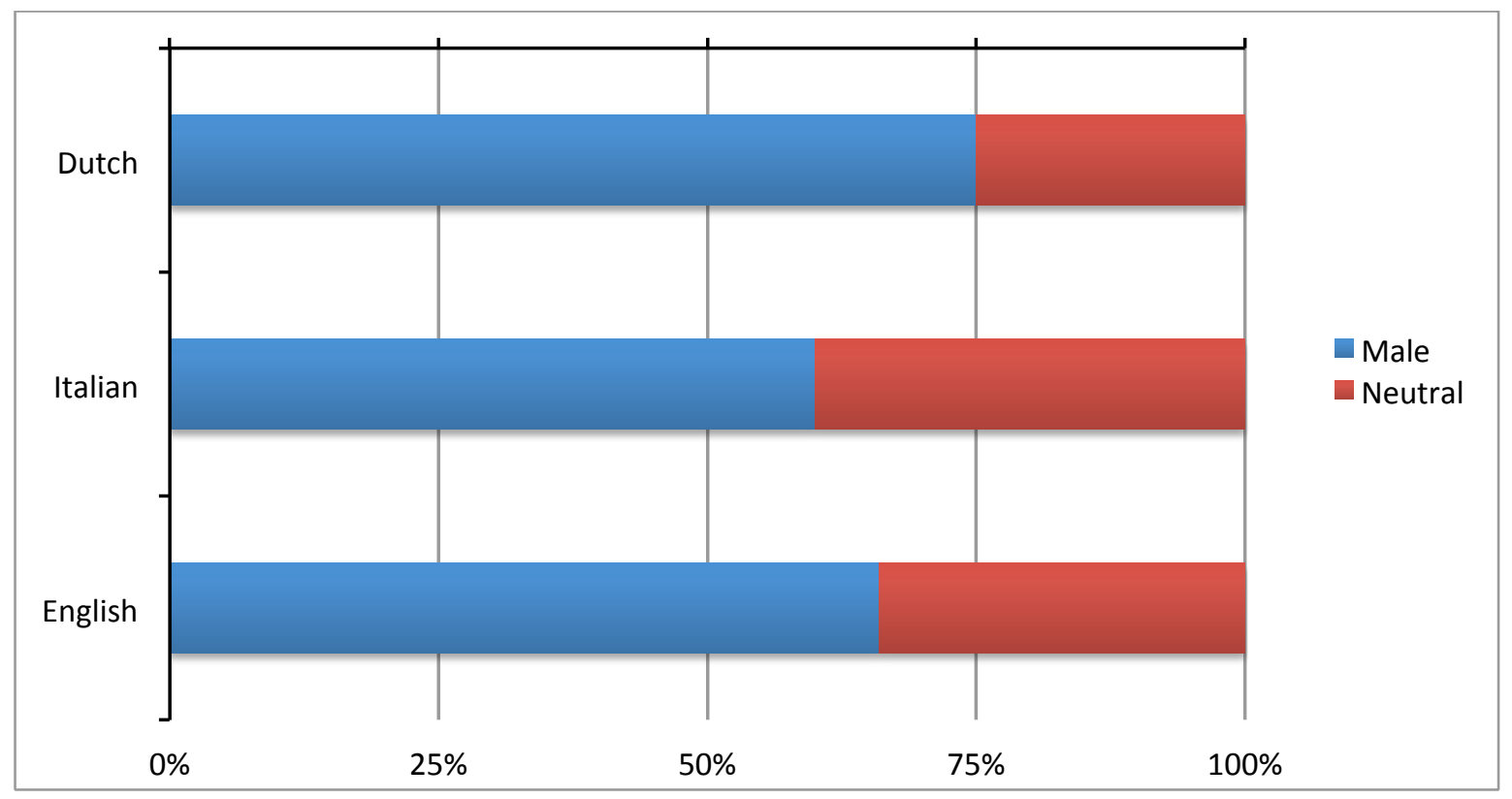

Based on Table 4 and accepting a source domain classification based on the BSRI is valid to determine the "familiarity" of source domains -- and hence metaphors to each of the genders-the conclusion should be that the majority of these metaphors come from worlds familiar to men and boys, not women and girls. In this respect it should be noted that our source domain "physical activity" refers to activities that require a lot of physical strength, something in which men clearly outperform women - evidence by separate competition in sports events for men and women, and the fact that the Championship match between men is considered more important than that between women, the former being scheduled as the final -and concluding-- event of a tournament (e.g. the women's final at Wimbledon is on Saturday, the men's one on Sunday). There is a slight difference between the three languages, with more masculine and less neutral source domains in Italian with respect to Dutch and English as Figure 2 shows.

A predominance of metaphors from masculine source domains comes as no surprise. Providing financially for the family has been a masculine endeavor from the start. Financial markets and institutions have in the past been literally a man's world, and with the family as the key unit of decision making when it comes to life cycle saving and investing, a predominance of masculine metaphors would not be surprising. Still, in our view, using merely the BSRI to categorize the source domains according to whether they belong more to the world of men or women is not enough to draw final conclusions on whether the language spoken in websites 
addressing beginning investors contributes to the gender gap in stock market participation and risk taking. Follow up research should shed more light on this. In this respect we are taking various routes in order to be able to identify objectively the degree of femininity/masculinity/neutrality of the source domains resulting from our metaphor analysis. To this end, we will 1) analyze occupational patters of men and women in the five domains found in the three countries analyzed here, 2) ask in each country a sample representative for the population how likely they think it is that men/women are active in each of these five domains, 3) detect implicit associations of men and women with these domains using implicit association tests $^{14}$, and 4) doing experiments to analyze which metaphors men and women use when they talk about (saving for) retirement. Moreover, in order to draw final conclusions we also need to compare metaphor used in the financial industry with that used in industries where we do not find a gender gap in decision-making and participation, or in industries that are mainly targeting women. As our final purpose is to assess whether the gender stereotype (masculinity) of the metaphors' source domains may have an impact on attitudes and behavior, we will design "feminine" counterparts and carry out experiments where participants are randomly selected into either the traditional or the alternative condition. In the selection of counterparts and in the analysis of the impact it will be necessary to pay attention to whether they are agent or object, and alive-moribund- dead. Otherwise, it may not be possible to draw conclusions as the metaphors may differ in more than one (masculine/feminine source domain) aspect.

\section{Discussion}

Our findings indicate that in the three languages studied -Dutch, English and Italian-metaphorical expressions in investor communication come from the same source domains, and that these domains are, in the metaphorical sense, more masculine than feminine. This is not to say that men like to go to war, or even that they have actually served in the military, and that women, on the other hand, do not like sports or are not interested in heavy physical activity. Rather, the metaphors evoke images of worlds that are, or were, populated more by men than by women, or worlds and activities that are (perhaps unconsciously) considered to be more appropriate for, or more likely to carried out by, men than by women - just as the word "diet" evokes images of a world to which men feel they do not or should not belong, even though men

14 The IAT is designed by Harvard Business School, see https://implicit.harvard.edu/implicit 
are interested in the way they look. Being part of System 1 way of thinking, this is not a conscious process, but unconscious, automatic, based on gender stereotypes that we have been grown up with. What is more, people are (linguists excluded, perhaps) unaware of the fact that the metaphorical expression "building your portfolio" is not neutral - until we realize that "knitting your portfolio" sounds, well, different. ${ }^{15}$

Some may argue that the source domain of the metaphors in investor communication is the result, not one of the causes of the gender gap in financial attitudes and decision-making. And indeed, our finding that the metaphors in the language of investment come from domains that are associated more with men than with women is not surprising. The financial sector has always been a man's world, and in the not-too distant past, women worked only if they did not have a spouse, or the spouse did have no or insufficient income. Up until the 1960s, it was common for women to be fired as soon as they got married, and that a woman's signature did not have contractual value. ${ }^{16}$ In the past, sons, not daughters, inherited the family's fortune, the one investment decision made by upper class women was choosing (or rather, being chosen by) a wealthy husband. The man used to be the only or main income earner and investment decisions, if any, were taken at the household, not individual level. Even finance theory usually assumes a unitary financial consumer (Donni and Chiappori 2011; Chiappori 2013; for a critical review, see Attanasio and Weber 2010). Research into differences in financial planning preferences within the family is of a recent date (Chiappori 2013; Browning et al 2014). This may also explain why gender marketing, so common for most consumer products is virtually absent for financial products and services.

Be that as it may, the world has changed, and due to socio-demographics, labor market participation and changes in social security, men and women need to take care of their financial future both as individuals and as household members. Hence, even if the language used in investor communication is the result of the financial sector historically being a man's world, it

\footnotetext{
15 In this paper we merely address he question whether investor language may, through its metaphors, discourage women from financial participation and risk taking. We do not discuss whether, if so, these metaphors should be replaced by ones coming from feminine source domains. Some women may feel that feminine metaphors should not be used because they would affirm women's stereotypical roles. Others argue that sterotypical feminine activities are belittled precisely because women are regarded as inferior. Serano (2007) argues that contemporary culture "assigns negative connotations to, or trivializes, behaviours understood to be feminine such as gossiping, behaving emotionally or decorating", and criticizes the view that women's interest in aesthetics is "intended solely to entice or attract men". This would be in line with the fact that even high educated men with top positions are - to put it mildly - not at all ashamed to admit that they like watching soccer (EU) or American football (US), and that on Google "soccer victim" is a person whose nose was broken by a soccer ball at a concert by Rod Stewart, while "fashion victim" is a woman who changes her wardrobe too often.
}

16 For the Netherlands, the latter was the case until 1957. 
should not be a (psychological) barrier to the financial inclusion of women. Moreover, it cannot be excluded that the metaphors used push men towards more risk taking than it is actually in line with their true preferences. In fact, Brighenti and Lucarelli (2013) conclude that both men and women make risky decisions that are not in line with their actual preferences as measured through their skin reactions: men are less, and women more risk tolerant than it is suggested by their self-declared attitudes and their actual decisions.

Further research is needed to verify whether the metaphors in investor communication are indeed non-neutral. This needs to be done by comparing the effect of masculine metaphors with their feminine and neutral counterparts. It is something we are currently working on, using methods from Social Psychology (e.g. implicit association tests), Linguistics (analysis of spoken language in focus groups), Economics (surveys and lab experiments) and physiological reactions. In this respect it should be noted that Avery (2012) and Nobel (2013) find that men tend to avoid anything they perceive as feminine. It may be wise for them to do so, given that doing anything associated with femininity would harm their status (much more than a woman's status is hurt if she engages in stereotypical masculine activities). Moreover, expanding the sources analyzed, from investor websites to all media, is required to get a full grasp of the potential effect of language, through familiarity, on men and women's financial attitudes and behavior.

\section{Summary and conclusions}

This paper finds that the overwhelming majority of the metaphors in retail investor communication come from masculine source domains. Through various channels this may affect attitudes and behavior differently among men and women. The metaphors could result in feelings of familiarity and belonging among men, and trigger their propensity to risk taking, and not among women. Affect heuristic could be at work, inducing positive affect among men and negative affect among women, thus leading to lower risk perception and higher expected return among men, while increasing perceived risk and reducing expected return among women. It could therefore be that the language used in investor communication, through its metaphorical associations, contributes to explaining the gender gap in financial attitudes and behavior (stock market participation, portfolio risk taking). However, further research is required to substantiate this claim. Our main findings also indicate that the metaphors in investor communication, apart from their masculine features, come from source domains that are 
identical across the three languages studied here. This underscores that the use of metaphors in investor communication is not random.

Our analysis suggests that comparing the effects of the masculine metaphors found on financial attitudes and behavior of both men and women with their feminine counterparts is worthwhile. If a different impact on attitudes and behavior were found, this would have several implications. Depending on the effects found, it could imply that investor language is nonneutral and, hence, it may affect attitudes and decisions. If the effects differ between men and women, metaphor analysis could contribute to explaining the gender gap in financial attitudes and decision-making. It would imply not only that financial markets are actually not a gender level playing field, but also that investor communication may bias people, both men and women or one of the genders, toward making decisions that are not in line with their true preferences. Given the importance given by policymakers to help investors make adequate decisions (see, for instance, Mifid rules), this would have implications for an evaluation of current investor protection policies.

Finally, further research should reveal whether taking into account the effect of metaphors could promote financial inclusion of women. With more pension risk transferred to individuals, increased and increasing labor market participation by women, and an increasing need for women to manage their own wealth and take care of their own financial security in retirement (as a result of divorce and reduction of survivors' benefits), the need for understanding how to effectively reach and include all financial consumers is extremely important and has practical relevance not only for policy makers and financial sector supervisors and regulators, but also for the financial industry.

\section{References}

Aarts, H. and A. Dijksterhuis (2003). The Silence of the Library: Environment, Situational Norm and Social Behavior, Journal of Personality and Social Psychology 84 (3): 18-28.

Akpinar, E. and J. Berger (2014). How Sense Shape Language: The Cultural Success of Sensory Metaphors (under revision).

Alhakami, A. S., and P. Slovic (1994). A Psychological Study of the Inverse Relationship Between Perceived Risk and Perceived Benefit, Risk Analysis 14 (6): 1085-1096.

Attanasio, O. P. and G Weber (2010). Consumption and Saving: Models of Inter-temporal Allocation and Their Implications for Public Policy, NBER Working Paper 15756.

Avery, J. J. (2012). Defending the Markers of Masculinity: Consumer Resistance to Brand 
Gender-Bending, International Journal of Research in Marketing 29 (4): 322-336.

Bem, S. L. (1974). The Measurement of Psychological Androgyny, Journal of Consulting and Clinical Psychology 42: 155-156

Boers, F. and M. Demecheleers (1997). A Few Metaphorical Models in (Western) Economic Discourse, Liebert, W., G. Redeker and L. Waugh (eds), Discourse and Perspective in Cognitive Linguistics 151, John Benjamins Publishing.

Boyle, P., L. Garlappi, L. R. Uppal and T. Wang, (2012). Keynes Meets Markowitz: The Tradeoff between Familiarity and Diversification, Management Science 58(2): 253-272.

Brighenti, G. and C. Lucarelli (2013). Does Gender Influence Risk Attitude and Ambiguity Aversion? When Psycho-Physiological Measurements Contradict Social Beliefs. SSRN Working paper 2265502.

Browning, M., P. Chiappori and Y. Weiss (2014). Economics of the Family, Cambridge Surveys of Economic Literature, Cambridge University Press.

Charteris-Black, J. and C. Seale (2010). Gender and the Language of Illness, Basingstoke: Palgrave Macmillan.

Chen, M. K. (2013). The Effect of Language on Economic Behavior: Evidence from Saving Rates, Health Behaviors, and Retirement Assets. American Economic Review. 103 (2): 690-731.

Chiappori, P. (2013). Risk Sharing Within the Household, CINTIA Kick-Off Conference on Longevity and Risk During the Great Recession (December 13, Venice, Italy).

Coval, J. D. and T.J. Moskowitz (1999). Home Bias at Home: Local Equity Preference in Domestic Portfolios, Journal of Finance 54 (6): 2045-2074.

Crystal, D. (2003). English as a Global Language. Cambridge: Cambridge University Press.

Dimmock, S.G., R. Kouwenberg, O.S. Mitchell, K. Peijnenburg (2013). Ambiguity Aversion and Household Portfolio Choice: Empirical Evidence. NBER Working paper 18743.

Donni, O. and P. Chiappori (2011). Nonunitary Models of Household Behavior: A Survey of the Literature, in Household Economic Behaviors International Series on Consumer Science, Springer: 1-40.

Doskeland, T. and H. K. Hvide (2011). Do Individual Investors Have Asymmetric Information Based on Work Experience? Journal of Finance 66 (3): 1011-1041.

Eckel, C., and P. Grossman (2002). Differences in the Economic Decisions of Men and Women: Experimental Evidence, Amsterdam: Elsevier.

Driver Leinbach, M., B. E. Hort, B. I. Fagot (1997). Bears Are for Boys: Metaphorical Associations in Young Children's Gender Stereotypes, Cognitive Development 12 (1): 107-130. 
Ellsberg, D. (1961). Risk, Ambiguity and the Savage Axioms, The Quarterly Journal of Economics, 75 (4): 643-69.

Epstein, S. (1994). Integration of the Cognitive and Psychodynamic Unconscious, American Psychologist 49 (8): 709-724.

European Commission (2013). The Gender Gap in Pensions in the EU, Publications Office of the European Union, Luxemburg, ISBN 978-92-79-2991: 4-8.

Epstein, S. (1994). Integration of the Cognitive and Psychodynamic Unconscious, American Psychologist 49 (8): 709-724.

French, K. and James P. (1991). Investor Diversification and International Equity Markets, American Economic Review 81 (2): 222-226.

Gay, V., E. Santacreu-Vasut and A. Shoham (2013). The Grammatical Origins of Gender Roles, BEHL Working Paper (WP 2013-03).

Guo, S. (2013). Metaphor Studies from the Perspective of Critical Discourse Analysis: A Case Study of Business Acquisition, Theory and Practice in Language Studies 3 (3): 475-481.

Heath, C. and A. Tversky (1991). Preference and Beliefs: Ambiguity and Competence in Choice under Uncertainty, Journal of Risk and Uncertainty 4 (1): 5-28.

Holt, C. L. and J. B. Ellis (1998). Assessing the Current Validity of the Bem Sex-Role Inventory, Sex Roles 39 (11/12): 929-941.

Huberman, G. (2001). Familiarity Breeds Investment, Review of Financial Studies 14 (3): 659680 .

Koller, V. (2004). Metaphor and Gender in Business Media Discourse: A Critical Cognitive Study. Basingstoke: Palgrave Macmillan.

Laibson, D. I. (2005). Impatience and Savings, NBER Research Summary (Fall 2005): 4-8.

Lakoff, G. (1987). Women, Fire, and Dangerous Things: What Categories Reveal About the Mind, Chicago: University of Chicago Press.

Lakoff, G. and M. Johnson (1980). Metaphors We Live By, Chicago: University of Chicago Press.

Lakoff, G. and M. Turner (1989). More than Cool Reason: A Field Guide to Poetic Metaphors, Chicago University Press, Chicago.

Liang, H., C. Marquis, L. Renneboog, S.L. Sun (2014). Speaking Corporate Social Responsibility, Harvard Business School Organizational Behavior Unit Working Paper (WP 14-082).

Merton, R.C. (1987). A Simple Model Of Capital Market Equilibrium With Incomplete Information, Journal Of Finance 42: 483-510. 
Morris, M., O. Sheldon, D. Ames, M. Young (2007). Metaphors and the Market: Consequences and Preconditions of Agent and Object Metaphors in Stock Market Commentary, Organizational Behavior and Human Decision Processes 102: 174-192.

Müller, C. (2008). Metaphors Dead and Alive, Sleeping and Waking. Chicago and London: University of Chicago Press.

Nobel, Carmen (2013). Should Men's Products Fear a Woman's Touch? Harvard Business School Working Knowledge. Boston: Harvard Business School.

Oberlechner, T., T. Slunecko and N. Kronberger (2004), Surfing the money tides: Understanding the foreign exchange market through metaphors. British journal of social psychology, 43 (1), 133-156

OECD (2013). OECD/INFE Policy Guidance on Addressing Women's and Girls' Needs for Financial Awareness and Education.

Ortony, A. (1993). Metaphor and thought, Cambridge: Cambridge University Press.

Pragglejaz Group (2007). MIP: A Method for Identifying Metaphorically Used Words in Discourse, Metaphor and Symbol 22 (1): 1-19.

Prast, H., M. Rossi, C. Torricelli and C. Druta (2013). Do Women Prefer Pink? The Effect of a Gender Stereotypical Stock Portfolio on Investing Decisions, Collegio Carlo Alberto Working Paper 338 (Netspar DP 01/2014-009).

Prast, H., A. Van Soest (2014). Pensioenbewustzijn (Pension Awareness), Netspar Panel Paper 37: 1-83.

Sadoski, M., E.T. Goetz and J.B. Fritz (1993). Impact of Concreteness on Comprehensibility, Interest, and Memory for Text: Implications for Dual Coding Theory and Text Design. Journal of Educational Psychology 85 (2): 291-304.

Santacreu-Vasut, E., Shoham, A. And V. Gay. (2013). Do Female/Male Distinctions in Language Matter? Evidence from Gender Political Quotas, Applied Economic Letters 20 (5): 495-498.

Saramago, J. (2010) [2008]. The Elephant's Journey. New York: Random House Publishers.

Serano, J. (2007). Whipping Girl: A Transsexual Woman on Sexism and the Scapegoating of Femininity, Berkeley (CA): Seal Press.

Seymour-Smith, S., M. Wetherell and A. Phoenix (2002). 'My Wife Ordered Me to Come!': A Discursive Analysis of Doctors' and Nurses' Accounts of Men's Use of General Practitioners. Journal of Health Psychology, 7 (3): 253-267.

Slovic, P., E. Peters, M. Finucane, D. D. McGregor (2005). Affect, Risk and Decision Making, Health Psychology 24 (4): 35-40.

Steen, G. (2002). Towards a Procedure for Metaphor Identification. Language and Literature, 11(1): 17-33. 
Steen, G. (2007). Finding Metaphor in Discourse: Pragglejaz and Beyond, Cultura, lenguaje y representación / Culture, language and representation V: 9-25.

Tesar, L. and I. Werner (1995). Home Bias and High Turnover, Journal of International Money and Finance 14 (4): 467-492.

Wheeler, S. C. and J. Berger (2007). When the Same Prime Leads to Different Effects, Journal of Consumer Research 34 (3): 357-368.

Zajonc, R. B. (1968). Attitudinal Effects of Mere Exposure, Journal of Personality and Social Psychology 9 (2): 1-27.

Zajonc, R.B. (1980). Feeling and Thinking: Preferences Need No Inferences, American Psychologist 35 (2): 151-175. 
Our papers can be downloaded at:

http://cerp.carloalberto.org/en/publications

\section{CeRP Working Paper Series}

\begin{tabular}{|c|c|}
\hline$N^{\circ} 140 / 14$ & $\begin{array}{l}\text { Cecilia Boggio } \\
\text { Elsa Fornero } \\
\text { Henriette Prast } \\
\text { Jose Sanders }\end{array}$ \\
\hline$N^{\circ} 139 / 14$ & $\begin{array}{l}\text { Laura Bianchini } \\
\text { Margherita Borella }\end{array}$ \\
\hline$N^{\circ} 138 / 13$ & Claudio Morana \\
\hline $\mathrm{N}^{\circ} 137 / 13$ & Claudio Morana \\
\hline $\mathrm{N}^{\circ} 136 / 13$ & Anna Lo Prete \\
\hline$N^{\circ} 135 / 13$ & $\begin{array}{l}\text { Rik Dillingh } \\
\text { Henriette Prast } \\
\text { Mariacristina Rossi } \\
\text { Cesira Urzì Brancati }\end{array}$ \\
\hline
\end{tabular}

No 134/13 Annamaria Lusardi Olivia S. Mitchell

No 133/13 Annamaria Lusardi Pierre-Carl Michaud Olivia S. Mitchell

No 132/13 Riccardo Calcagno Sonia Falconieri

N 131/13 Riccardo Calcagno Maria Cesira Urzì Brancati

№130/12 Maela Giofré

$\mathrm{N}^{\circ}$ 129/12 Michele Belloni

Rob Alessie

Adriaan Kalwij

Chiara Marinacci

№ 128/12 Fabio Cesare Bagliano Claudio Morana

No 127/12 Mariacristina Rossi Serena Trucchi

No 126/11 Margherita Borella Flavia Coda Moscarola Mariacristina Rossi

№ 125/11 Carolina Fugazza

No 124/11 Agnese Romiti Mariacristina Rossi
Seven Ways to Knit Your Portfolio: Is Investor Communication Neutral?

Cognitive Functioning and Retirement in Europe

Insights on the global macro-finance interface: Structural sources of risk factors fluctuations and the cross-section of expected stock returns

New Insights on the US OIS Spreads Term Structure During the Recent Financial Turmoil

Inequality and the finance you know: does economic literacy matter?

The psychology and economics of reverse mortgage attitudes: evidence from the Netherlands

The Economic Importance of Financial Literacy: Theory and Evidence

Optimal Financial Knowledge and Wealth Inequality

Competition and dynamics of takeover contests

Do more financially literate households invest less in housing? Evidence from Italy

Financial Education, Investor Protection and International Portfolio Diversification

Lifetime Income and Old Age Mortality Risk in Italy over Two Decades

Determinants of US Financial Fragility Conditions

Liquidity Constraints and Labor Supply

(Un)expected retirement and the consumption puzzle

Tracking the Italian employees' TFR over their working life careers

Should we Retire Earlier in order to Look After our Parents? The Role of immigrants 


\begin{tabular}{|c|c|}
\hline $\mathrm{N}^{\circ} 123 / 11$ & $\begin{array}{l}\text { Elsa Fornero } \\
\text { Maria Cristina Rossi } \\
\text { Maria Cesira Urzì Brancati }\end{array}$ \\
\hline $\mathrm{N}^{\circ} 122 / 11$ & Serena Trucchi \\
\hline $\mathrm{N}^{\circ} 121 / 11$ & $\begin{array}{l}\text { Elsa Fornero } \\
\text { Chiara Monticone } \\
\text { Serena Trucchi }\end{array}$ \\
\hline $\mathrm{N}^{\circ} 120 / 11$ & $\begin{array}{l}\text { Giovanni Mastrobuoni } \\
\text { Filippo Taddei }\end{array}$ \\
\hline$N^{\circ} 119 / 11$ & $\begin{array}{l}\text { Maarten van Rooij } \\
\text { Annamaria Lusardi } \\
\text { Rob Alessie }\end{array}$ \\
\hline $\mathrm{N}^{\circ} 118 / 11$ & $\begin{array}{l}\text { Luca Beltrametti } \\
\text { Matteo Della Valle }\end{array}$ \\
\hline $\mathrm{N}^{\circ} 117 / 11$ & $\begin{array}{l}\text { Riccardo Calcagno } \\
\text { Chiara Monticone }\end{array}$ \\
\hline $\mathrm{N}^{\circ} 116 / 11$ & $\begin{array}{l}\text { Annamaria Lusardi } \\
\text { Daniel Schneider } \\
\text { Peter Tufano }\end{array}$ \\
\hline $\mathrm{N}^{\circ} 115 / 11$ & $\begin{array}{l}\text { Adele Atkinson } \\
\text { Flore-Anne Messy }\end{array}$ \\
\hline$N^{\circ} 114 / 11$ & $\begin{array}{l}\text { Leora Klapper } \\
\text { Georgios A. Panos }\end{array}$ \\
\hline$N^{\circ} 113 / 11$ & $\begin{array}{l}\text { Diana Crossan } \\
\text { David Feslier } \\
\text { Roger Hurnard }\end{array}$ \\
\hline $\mathrm{N}^{\circ} 112 / 11$ & $\begin{array}{l}\text { Johan Almenberg } \\
\text { Jenny Säve-Söderbergh }\end{array}$ \\
\hline $\mathrm{N}^{\circ} 111 / 11$ & $\begin{array}{l}\text { Elsa Fornero } \\
\text { Chiara Monticone }\end{array}$ \\
\hline $\mathrm{N}^{\circ} 110 / 11$ & $\begin{array}{l}\text { Rob Alessie } \\
\text { Maarten Van Rooij } \\
\text { Annamaria Lusardi }\end{array}$ \\
\hline$N^{\circ} 109 / 11$ & $\begin{array}{l}\text { Tabea Bucher-Koenen } \\
\text { Annamaria Lusardi }\end{array}$ \\
\hline$N^{\circ} 108 / 11$ & Shizuka Sekita \\
\hline$N^{\circ} 107 / 11$ & $\begin{array}{l}\text { Annamaria Lusardi } \\
\text { Olivia S. Mitchell }\end{array}$ \\
\hline$N^{\circ} 106 / 11$ & $\begin{array}{l}\text { Annamaria Lusardi } \\
\text { Olivia S. Mitchell }\end{array}$ \\
\hline$N^{\circ} 105 / 11$ & Agnese Romiti \\
\hline $\mathrm{N}^{\circ} 104 / 11$ & Ambrogio Rinaldi \\
\hline $\mathrm{N}^{\circ} 103 / 10$ & $\begin{array}{l}\text { Fabio Bagliano } \\
\text { Claudio Morana }\end{array}$ \\
\hline $\mathrm{N}^{\circ} 102 / 10$ & $\begin{array}{l}\text { Nuno Cassola } \\
\text { Claudio Morana }\end{array}$ \\
\hline
\end{tabular}

Explaining why, right or wrong, (Italian) households do not like reverse mortgages

How credit markets affect homeownership: an explanation based on differences between Italian regions

The effect of financial literacy on mortgage choices

Age Before Beauty? Productivity and Work vs. Seniority and Early Retirement

Financial Literacy, Retirement Planning, and Household Wealth

Does the implicit pension debt mean anything after all?

Financial Literacy and the Demand for Financial Advice

Financially Fragile Households: Evidence and Implications

Assessing financial literacy in 12 countries: an OECD Pilot Exercise

Financial Literacy and Retirement Planning in View of a Growing Youth Demographic: The Russian Case

Financial Literacy and Retirement Planning in New Zealand

Financial Literacy and Retirement Planning in Sweden

Financial Literacy and Pension Plan Participation in Italy

Financial Literacy, Retirement Preparation and Pension Expectations in the Netherlands

Financial Literacy and Retirement Planning in Germany

Financial Literacy and Retirement Planning in Japan

Financial Literacy and Retirement Planning in the United States

Financial Literacy Around the World: An Overview

Immigrants-Natives Complementarities in Production: Evidence from Italy

Pension awareness and nation-wide auto-enrolment: the Italian experience

The Great Recession: US dynamics and spillovers to the world economy

The 2007-? financial crisis: a money market perspective 


\begin{tabular}{|c|c|c|}
\hline $\mathrm{N}^{\circ} 101 / 10$ & Tetyana Dubovyk & Macroeconomic Aspects of Italian Pension Reforms of 1990s \\
\hline$N^{\circ} 100 / 10$ & $\begin{array}{l}\text { Laura Piatti } \\
\text { Giuseppe Rocco }\end{array}$ & L'educazione e la comunicazione previdenziale - Il caso italiano \\
\hline$N^{\circ} 99 / 10$ & $\begin{array}{l}\text { Fabio Bagliano } \\
\text { Claudio Morana }\end{array}$ & $\begin{array}{l}\text { The effects of US economic and financial crises on euro area } \\
\text { convergence }\end{array}$ \\
\hline$N^{\circ} 98 / 10$ & $\begin{array}{l}\text { Annamaria Lusardi } \\
\text { Daniel Schneider } \\
\text { Peter Tufano }\end{array}$ & The Economic Crisis and Medical Care Usage \\
\hline$N^{\circ} 97 / 10$ & $\begin{array}{l}\text { Carlo Maccheroni } \\
\text { Tiziana Barugola }\end{array}$ & $\begin{array}{l}\text { E se l'aspettativa di vita continuasse la sua crescita? Alcune } \\
\text { ipotesi per le generazioni italiane 1950-2005 }\end{array}$ \\
\hline$N^{\circ} 96 / 10$ & $\begin{array}{l}\text { Riccardo Calcagno } \\
\text { Mariacristina Rossi }\end{array}$ & Portfolio Choice and Precautionary Savings \\
\hline$N^{\circ} 95 / 10$ & $\begin{array}{l}\text { Flavia Coda Moscarola } \\
\text { Elsa Fornero } \\
\text { Mariacristina Rossi }\end{array}$ & $\begin{array}{l}\text { Parents/children “deals”: Inter-Vivos Transfers and Living } \\
\text { Proximity }\end{array}$ \\
\hline$N^{\circ} 94 / 10$ & $\begin{array}{l}\text { John A. List } \\
\text { Sally Sadoff } \\
\text { Mathis Wagner }\end{array}$ & $\begin{array}{l}\text { So you want to run an experiment, now what? Some Simple } \\
\text { Rules of Thumb for Optimal Experimental Design }\end{array}$ \\
\hline$N^{\circ} 93 / 10$ & Mathis Wagner & The Heterogeneous Labor Market Effects of Immigration \\
\hline$N^{\circ} 92 / 10$ & $\begin{array}{l}\text { Rob Alessie } \\
\text { Michele Belloni }\end{array}$ & Retirement choices in Italy: what an option value model tells us \\
\hline$N^{\circ} 91 / 09$ & $\begin{array}{l}\text { Annamaria Lusardi } \\
\text { Olivia S. Mitchell } \\
\text { Vilsa Curto }\end{array}$ & $\begin{array}{l}\text { Financial Literacy among the Young: } \\
\text { Evidence and Implications for Consumer Policy }\end{array}$ \\
\hline$N^{\circ} 90 / 09$ & $\begin{array}{l}\text { Annamaria Lusardi } \\
\text { Olivia S. Mitchell }\end{array}$ & $\begin{array}{l}\text { How Ordinary Consumers Make Complex Economic Decisions: } \\
\text { Financial Literacy and Retirement Readiness }\end{array}$ \\
\hline$N^{\circ} 89 / 09$ & Elena Vigna & $\begin{array}{l}\text { Mean-variance inefficiency of CRRA and CARA utility } \\
\text { functions for portfolio selection in defined contribution pension } \\
\text { schemes }\end{array}$ \\
\hline$N^{\circ} 88 / 09$ & Maela Giofré & Convergence of EMU Equity Portfolios \\
\hline$N^{\circ} 87 / 09$ & $\begin{array}{l}\text { Elsa Fornero } \\
\text { Annamaria Lusardi } \\
\text { Chiara Monticone }\end{array}$ & Adequacy of Saving for Old Age in Europe \\
\hline$N^{\circ} 86 / 09$ & $\begin{array}{l}\text { Margherita Borella } \\
\text { Flavia Coda Moscarola }\end{array}$ & $\begin{array}{l}\text { Microsimulation of Pension Reforms: Behavioural versus } \\
\text { Nonbehavioural Approach }\end{array}$ \\
\hline$N^{\circ} 85 / 09$ & $\begin{array}{l}\text { Cathal O’Donoghue } \\
\text { John Lennon } \\
\text { Stephen Hynes }\end{array}$ & $\begin{array}{l}\text { The Life-Cycle Income Analysis Model (LIAM): A Study of a } \\
\text { Flexible Dynamic Microsimulation Modelling Computing } \\
\text { Framework }\end{array}$ \\
\hline$N^{\circ} 84 / 09$ & Luca Spataro & $\begin{array}{l}\text { Il sistema previdenziale italiano dallo shock petrolifero del } 1973 \\
\text { al Trattato di Maastricht del } 1993\end{array}$ \\
\hline$N^{\circ} 83 / 09$ & $\begin{array}{l}\text { Annamaria Lusardi } \\
\text { Peter Tufano }\end{array}$ & Debt Literacy, Financial Experiences, and Overindebtedness \\
\hline$N^{\circ} 82 / 09$ & $\begin{array}{l}\text { Carolina Fugazza } \\
\text { Massimo Guidolin } \\
\text { Giovanna Nicodano }\end{array}$ & $\begin{array}{l}\text { Time and Risk Diversification in Real Estate Investments: } \\
\text { Assessing the Ex Post Economic Value }\end{array}$ \\
\hline$N^{\circ} 81 / 09$ & $\begin{array}{l}\text { Fabio Bagliano } \\
\text { Claudio Morana }\end{array}$ & $\begin{array}{l}\text { Permanent and Transitory Dynamics in House Prices and } \\
\text { Consumption: Cross-Country Evidence }\end{array}$ \\
\hline
\end{tabular}




\begin{tabular}{|c|c|}
\hline$N^{\circ} 80 / 08$ & Claudio Campanale \\
\hline$N^{\circ} 79 / 08$ & Annamaria Lusardi \\
\hline$N^{\circ} 78 / 08$ & $\begin{array}{l}\text { Margherita Borella } \\
\text { Giovanna Segre }\end{array}$ \\
\hline $\mathrm{N}^{\circ} 77 / 08$ & $\begin{array}{l}\text { Giovanni Guazzarotti } \\
\text { Pietro Tommasino }\end{array}$ \\
\hline$N^{\circ} 76 / 08$ & $\begin{array}{l}\text { Riccardo Calcagno } \\
\text { Elsa Fornero } \\
\text { Mariacristina Rossi }\end{array}$ \\
\hline$N^{\circ} 75 / 08$ & $\begin{array}{l}\text { Harold Alderman } \\
\text { Johannes Hoogeveen } \\
\text { Mariacristina Rossi }\end{array}$ \\
\hline$N^{\circ} 74 / 08$ & Maela Giofré \\
\hline$N^{\circ} 73 / 08$ & $\begin{array}{l}\text { Michele Belloni } \\
\text { Rob Alessie }\end{array}$ \\
\hline$N^{\circ} 72 / 08$ & $\begin{array}{l}\text { Annamaria Lusardi } \\
\text { Olivia Mitchell }\end{array}$ \\
\hline $\mathrm{N}^{\circ} 71 / 07$ & Flavia Coda Moscarola \\
\hline$N^{\circ} 70 / 07$ & $\begin{array}{l}\text { Radha Iyengar } \\
\text { Giovanni Mastrobuoni }\end{array}$ \\
\hline$N^{\circ} 69 / 07$ & $\begin{array}{l}\text { Carolina Fugazza } \\
\text { Massimo Guidolin } \\
\text { Giovanna Nicodano }\end{array}$ \\
\hline$N^{\circ} 68 / 07$ & $\begin{array}{l}\text { Massimo Guidolin } \\
\text { Giovanna Nicodano }\end{array}$ \\
\hline$N^{\circ} 67 / 07$ & $\begin{array}{l}\text { Carolina Fugazza } \\
\text { Maela Giofré } \\
\text { Giovanna Nicodano }\end{array}$ \\
\hline$N^{\circ} 66 / 07$ & $\begin{array}{l}\text { Maarten van Rooij } \\
\text { Annamaria Lusardi } \\
\text { Rob Alessie }\end{array}$ \\
\hline$N^{\circ} 65 / 07$ & Annamaria Lusardi \\
\hline$N^{\circ} 64 / 07$ & $\begin{array}{l}\text { Carlo Casarosa } \\
\text { Luca Spataro }\end{array}$ \\
\hline$N^{\circ} 63 / 07$ & Claudio Campanale \\
\hline$N^{\circ} 62 / 07$ & $\begin{array}{l}\text { Margherita Borella } \\
\text { Elsa Fornero } \\
\text { Mariacristina Rossi }\end{array}$ \\
\hline
\end{tabular}

Learning, Ambiguity and Life-Cycle Portfolio Allocation

Increasing the Effectiveness of Financial Education in the Workplace

Le pensioni dei lavoratori parasubordinati: prospettive dopo un decennio di gestione separata

The Annuity Market in an Evolving Pension System: Lessons from Italy

The Effect of House Prices on Household Saving: The Case of Italy

Preschool Nutrition and Subsequent Schooling Attainment:

Longitudinal Evidence from Tanzania

Information Asymmetries and Foreign Equity Portfolios:

Households versus Financial Investors

The Importance of Financial Incentives on Retirement Choices: New Evidence for Italy

Planning and Financial Literacy: How Do Women Fare?

Women participation and caring decisions: do different institutional frameworks matter? A comparison between Italy and The Netherlands

The Political Economy of the Disability Insurance. Theory and Evidence of Gubernatorial Learning from Social Security Administration Monitoring

Investing in Mixed Asset Portfolios: the Ex-Post Performance

Small Caps in International Diversified Portfolios

International Diversification and Labor Income Risk

Financial Literacy and Stock Market Participation

Household Saving Behavior: The Role of Literacy, Information and Financial Education Programs

(Updated version June 08: "Financial Literacy: An Essential Tool for Informed Consumer Choice?”)

Rate of Growth of Population, Saving and Wealth in the Basic

Life-cycle Model when the Household is the Decision Unit

Life-Cycle Portfolio Choice: The Role of Heterogeneous UnderDiversification

Does Consumption Respond to Predicted Increases in Cash-onhand Availability? Evidence from the Italian "Severance Pay" 


\begin{tabular}{|c|c|}
\hline$N^{\circ} 61 / 07$ & Irina Kovrova \\
\hline$N^{\circ} 60 / 07$ & $\begin{array}{l}\text { Riccardo Cesari } \\
\text { Giuseppe Grande } \\
\text { Fabio Panetta }\end{array}$ \\
\hline$N^{\circ} 59 / 07$ & $\begin{array}{l}\text { Riccardo Calcagno } \\
\text { Roman Kraeussl } \\
\text { Chiara Monticone }\end{array}$ \\
\hline $\mathrm{N}^{\circ} 58 / 07$ & $\begin{array}{l}\text { Elisa Luciano } \\
\text { Jaap Spreeuw } \\
\text { Elena Vigna }\end{array}$ \\
\hline $\mathrm{N}^{\circ} 57 / 07$ & $\begin{array}{l}\text { Giovanni Mastrobuoni } \\
\text { Matthew Weinberg }\end{array}$ \\
\hline$N^{\circ} 56 / 07$ & $\begin{array}{l}\text { John A. Turner } \\
\text { Satyendra Verma }\end{array}$ \\
\hline$N^{\circ} 55 / 06$ & Antonio Abatemarco \\
\hline$N^{\circ} 54 / 06$ & $\begin{array}{l}\text { Annamaria Lusardi } \\
\text { Olivia S. Mitchell }\end{array}$ \\
\hline$N^{\circ} 53 / 06$ & Giovanni Mastrobuoni \\
\hline$N^{\circ} 52 / 06$ & $\begin{array}{l}\text { Luigi Guiso } \\
\text { Tullio Jappelli }\end{array}$ \\
\hline$N^{\circ} 51 / 06$ & Giovanni Mastrobuoni \\
\hline$N^{\circ} 50 / 06$ & $\begin{array}{l}\text { Andrea Buffa } \\
\text { Chiara Monticone }\end{array}$ \\
\hline$N^{\circ} 49 / 06$ & Mariacristina Rossi \\
\hline $\mathrm{N}^{\circ} 48 / 06$ & $\begin{array}{l}\text { Onorato Castellino } \\
\text { Elsa Fornero }\end{array}$ \\
\hline $\mathrm{N}^{\circ} 47 / 06$ & $\begin{array}{l}\text { Michele Belloni } \\
\text { Carlo Maccheroni }\end{array}$ \\
\hline$N^{\circ} 46 / 05$ & $\begin{array}{l}\text { Annamaria Lusardi } \\
\text { Olivia S. Mitchell }\end{array}$ \\
\hline$N^{\circ} 45 / 05$ & Claudio Campanale \\
\hline$N^{\circ} 44 / 05$ & Henrik Cronqvist \\
\hline$N^{\circ} 43 / 05$ & $\begin{array}{l}\text { John Beshears } \\
\text { James J. Choi } \\
\text { David Laibson } \\
\text { Brigitte C. Madrian }\end{array}$ \\
\hline$N^{\circ} 42 / 05$ & $\begin{array}{l}\text { Margherita Borella } \\
\text { Flavia Coda Moscarola }\end{array}$ \\
\hline$N^{\circ} 41 / 05$ & $\begin{array}{l}\text { Massimo Guidolin } \\
\text { Giovanna Nicodano }\end{array}$ \\
\hline$N^{\circ} 40 / 05$ & $\begin{array}{l}\text { Carolina Fugazza } \\
\text { Massimo Guidolin } \\
\text { Giovanna Nicodano }\end{array}$ \\
\hline
\end{tabular}

Effects of the Introduction of a Funded Pillar on the Russian Household Savings: Evidence from the 2002 Pension Reform La Previdenza Complementare in Italia:

Caratteristiche, Sviluppo e Opportunità per i Lavoratori

An Analysis of the Effects of the Severance Pay Reform on Credit to Italian SMEs

Modelling Stochastic Mortality for Dependent Lives

Heterogeneity in Intra-Monthly Consumption. Patterns, SelfControl, and Savings at Retirement

Why Some Workers Don't Take 401(k) Plan Offers: Inertia versus Economics

On the Measurement of Intra-Generational Lifetime Redistribution in Pension Systems

Baby Boomer Retirement Security: The Roles of Planning, Financial Literacy, and Housing Wealth

Labor Supply Effects of the Recent Social Security Benefit Cuts: Empirical Estimates Using Cohort Discontinuities

Information Acquisition and Portfolio Performance

The Social Security Earnings Test Removal. Money Saved or Money Spent by the Trust Fund?

Do European Pension Reforms Improve the Adequacy of Saving?

Examining the Interaction between Saving and Contributions to Personal Pension Plans. Evidence from the BHPS

Public Policy and the Transition to Private Pension Provision in the United States and Europe

Actuarial Neutrality when Longevity Increases: An Application to the Italian Pension System

Financial Literacy and Planning: Implications for Retirement Wellbeing

Increasing Returns to Savings and Wealth Inequality

Advertising and Portfolio Choice

The Importance of Default Options for Retirement Saving Outcomes: Evidence from the United States

Distributive Properties of Pensions Systems: a Simulation of the Italian Transition from Defined Benefit to Defined Contribution Small Caps in International Equity Portfolios: The Effects of Variance Risk.

Investing for the Long-Run in European Real Estate. Does Predictability Matter? 


\begin{tabular}{|c|c|}
\hline$N^{\circ} 39 / 05$ & Anna Rita Bacinello \\
\hline$N^{\circ} 38 / 05$ & $\begin{array}{l}\text { Carolina Fugazza } \\
\text { Federica Teppa }\end{array}$ \\
\hline$N^{\circ} 37 / 04$ & Jay Ginn \\
\hline$N^{\circ} 36 / 04$ & Laurence J. Kotlikoff \\
\hline$N^{\circ} 35 / 04$ & $\begin{array}{l}\text { Monika Bütler } \\
\text { Olivia Huguenin } \\
\text { Federica Teppa }\end{array}$ \\
\hline$N^{\circ} 34 / 04$ & Chourouk Houssi \\
\hline$N^{\circ} 33 / 04$ & $\begin{array}{l}\text { Elsa Fornero } \\
\text { Carolina Fugazza } \\
\text { Giacomo Ponzetto }\end{array}$ \\
\hline$N^{\circ} 32 / 04$ & $\begin{array}{l}\text { Angelo Marano } \\
\text { Paolo Sestito }\end{array}$ \\
\hline$N^{\circ} 31 / 03$ & Giacomo Ponzetto \\
\hline$N^{\circ} 30 / 03$ & $\begin{array}{l}\text { Bas Arts } \\
\text { Elena Vigna }\end{array}$ \\
\hline$N^{\circ} 29 / 02$ & Marco Taboga \\
\hline $\mathrm{N}^{\circ} 28 / 02$ & Luca Spataro \\
\hline $\mathrm{N}^{\circ} 27 / 02$ & Reinhold Schnabel \\
\hline $\mathrm{N}^{\circ} 26 / 02$ & E. Philip Davis \\
\hline$N^{\circ} 25 / 02$ & $\begin{array}{l}\text { Edmund Cannon } \\
\text { Ian Tonks }\end{array}$ \\
\hline$N^{\circ} 24 / 02$ & $\begin{array}{l}\text { Laura Ballotta } \\
\text { Steven Haberman }\end{array}$ \\
\hline$N^{\circ} 23 / 02$ & Ermanno Pitacco \\
\hline $\mathrm{N}^{\circ} 22 / 02$ & $\begin{array}{l}\text { Chris Soares } \\
\text { Mark Warshawsky }\end{array}$ \\
\hline $\mathrm{N}^{\circ} 21 / 02$ & $\begin{array}{l}\text { Olivia S. Mitchell } \\
\text { David McCarthy }\end{array}$ \\
\hline$N^{\circ} 20 / 02$ & Mauro Mastrogiacomo \\
\hline$N^{\circ} 19 / 02$ & $\begin{array}{l}\text { Paolo Battocchio } \\
\text { Francesco Menoncin }\end{array}$ \\
\hline$N^{\circ} 18 / 02$ & Francesco Daveri \\
\hline$N^{\circ} 17 / 02$ & $\begin{array}{l}\text { Richard Disney and } \\
\text { Sarah Smith }\end{array}$ \\
\hline$N^{\circ} 16 / 01$ & $\begin{array}{l}\text { Estelle James and } \\
\text { Xue Song }\end{array}$ \\
\hline
\end{tabular}

Modelling the Surrender Conditions in Equity-Linked Life Insurance

An Empirical Assessment of the Italian Severance Payment (TFR)

Actuarial Fairness or Social Justice?

A Gender Perspective on Redistribution in Pension Systems

Pensions Systems and the Intergenerational Distribution of Resources

What Triggers Early Retirement. Results from Swiss Pension Funds

Le Vieillissement Démographique :

Problématique des Régimes de Pension en Tunisie

A Comparative Analysis of the Costs of Italian Individual Pension Plans

Older Workers and Pensioners: the Challenge of Ageing on the Italian Public Pension System and Labour Market

Risk Aversion and the Utility of Annuities

A Switch Criterion for Defined Contribution Pension Schemes

The Realized Equity Premium has been Higher than Expected: Further Evidence

New Tools in Micromodeling Retirement Decisions: Overview and Applications to the Italian Case

Annuities in Germany before and after the Pension Reform of 2001

Issues in the Regulation of Annuities Markets

The Behaviour of UK Annuity Prices from 1972 to the Present

Valuation of Guaranteed Annuity Conversion Options

Longevity Risk in Living Benefits

Annuity Risk: Volatility and Inflation Exposure in Payments from Immediate Life Annuities

Annuities for an Ageing World

Dual Retirement in Italy and Expectations

Optimal Portfolio Strategies with Stochastic Wage Income and Inflation: The Case of a Defined Contribution Pension Plan

Labor Taxes and Unemployment: a Survey of the Aggregate Evidence

The Labour Supply Effect of the Abolition of the Earnings Rule for Older Workers in the United Kingdom

Annuities Markets Around the World: Money’s Worth and Risk Intermediation 


\begin{tabular}{|c|c|c|}
\hline$N^{\circ} 15 / 01$ & Estelle James & $\begin{array}{l}\text { How Can China Solve ist Old Age Security Problem? The } \\
\text { Interaction Between Pension, SOE and Financial Market Reform }\end{array}$ \\
\hline$N^{\circ} 14 / 01$ & Thomas H. Noe & Investor Activism and Financial Market Structure \\
\hline$N^{\circ} 13 / 01$ & Michela Scatigna & Institutional Investors, Corporate Governance and Pension Funds \\
\hline$N^{\circ} 12 / 01$ & Roberta Romano & $\begin{array}{l}\text { Less is More: Making Shareholder Activism a Valuable } \\
\text { Mechanism of Corporate Governance }\end{array}$ \\
\hline$N^{\circ} 11 / 01$ & $\begin{array}{l}\text { Mara Faccio and Ameziane } \\
\text { Lasfer }\end{array}$ & $\begin{array}{l}\text { Institutional Shareholders and Corporate Governance: The Case } \\
\text { of UK Pension Funds }\end{array}$ \\
\hline$N^{\circ} 10 / 01$ & $\begin{array}{l}\text { Vincenzo Andrietti and Vincent } \\
\text { Hildebrand }\end{array}$ & $\begin{array}{l}\text { Pension Portability and Labour Mobility in the United States. } \\
\text { New Evidence from the SIPP Data }\end{array}$ \\
\hline$N^{\circ} 9 / 01$ & Hans Blommestein & $\begin{array}{l}\text { Ageing, Pension Reform, and Financial Market Implications in } \\
\text { the OECD Area }\end{array}$ \\
\hline$N^{\circ} 8 / 01$ & Margherita Borella & $\begin{array}{l}\text { Social Security Systems and the Distribution of Income: an } \\
\text { Application to the Italian Case }\end{array}$ \\
\hline$N^{\circ} 7 / 01$ & Margherita Borella & $\begin{array}{l}\text { The Error Structure of Earnings: an Analysis on Italian } \\
\text { Longitudinal Data }\end{array}$ \\
\hline$N^{\circ} 6 / 01$ & Flavia Coda Moscarola & $\begin{array}{l}\text { The Effects of Immigration Inflows on the Sustainability of the } \\
\text { Italian Welfare State }\end{array}$ \\
\hline$N^{\circ} 5 / 01$ & Vincenzo Andrietti & $\begin{array}{l}\text { Occupational Pensions and Interfirm Job Mobility in the } \\
\text { European Union. Evidence from the ECHP Survey }\end{array}$ \\
\hline$N^{\circ} 4 / 01$ & Peter Diamond & Towards an Optimal Social Security Design \\
\hline$N^{\circ} 3 / 00$ & $\begin{array}{l}\text { Emanuele Baldacci } \\
\text { Luca Inglese }\end{array}$ & $\begin{array}{l}\text { Le caratteristiche socio economiche dei pensionati in Italia. } \\
\text { Analisi della distribuzione dei redditi da pensione (only available } \\
\text { in the Italian version) }\end{array}$ \\
\hline $\mathrm{N}^{\circ} 2 / 00$ & $\begin{array}{l}\text { Pier Marco Ferraresi } \\
\text { Elsa Fornero }\end{array}$ & $\begin{array}{l}\text { Social Security Transition in Italy: Costs, Distorsions and (some) } \\
\text { Possible Correction }\end{array}$ \\
\hline$N^{\circ} 1 / 00$ & Guido Menzio & Opting Out of Social Security over the Life Cycle \\
\hline
\end{tabular}

